\title{
PHÂN TÍCH HIỆN TRẠNG PHÂN BỐ DÒNG CHẢY VÀ ĐÁNH GIÁ ẢNH HƯởNG CỦA CÁC DƯ ÁN TƯớI ĐẾN PHÂN BỐ DÒNG CHẢY TẠI LƯU VỰC SÔNG MÊ CÔNG
}

\author{
Nguyễn Anh Đức ${ }^{1}$, Trần Anh Phương ${ }^{1}$, Nguyễn Đình Đạt ${ }^{2}$, Nguyễn Huy Phương $^{2}$, \\ Phạm Tường ${ }^{2}$, Phạm Nhật Anh'
}

Tóm tắt: Nghiên cứu này tập trung phân tích hiện trạng phân bố dòng chảy và đánh giá tác động của các dụ án phát triển tuới, một trong nhũng phát triển sử dụng nước "nóng” trên lưu vưc bên cạnh phát triển thủy điện, đến phân phối dòng chảy lưu vực sông Mê Công. Kết quả tính toán cho thấy, dòng chảy tập trung chủ yếu vào mùa mua (86\%) đã gây ra tình trạng lũ lụt vào mùa mura và hạn hán vào mùa khô. Trong số các nước trên lưu vực, Lào đóng góp dòng chảy vào đồng bằng sông Cưu Long lớn nhất (46\%), tiếp theo sau bởi Trung Quốc (15\%). Nếu các công trình khai thác sủ dụng nuớc được thực hiện nhu kế hoạch đến năm 2060 thì nhìn chung tổng dòng chảy mùa mua và dòng chảy năm trên toàn lưu vưc giảm. Nếu các hồ chứa tham gia vào điều tiết dòng chảy thì sự khác biệt giữa mùa mura và mùa khô trên phần luu vực thuộc địa phận Trung Quốc, Lào và một phần Campuchia (7C) giảm đi. Với Thái Lan, do lấy nước tuơoi tù sông Mê Công vào phục vu phát triển nông nghiệp, dòng chảy các mùa và tổng dòng chảy năm ở vùng $5 T$ đều tăng. Dòng chảy tù lư vực Sesan-Srepok của Việt Nam (7V) giảm 8,1\% do nhu cầu sủ dụng nước tăng. Nếu các hồ chứa không tham gia vào điều tiết dòng chảy thì dòng chảy các mùa, đặc biệt là mùa khô trên toàn luu vưc (ngoại trù vùng 5T) giảm mạnh. Kết quả của nghiên cứu này sẽ cũng cấp cơ sở khoa học cần thiết cho công tác đàm phán, hợp tác giữa Việt Nam với các quốc gia trên lưu vực chia sẻ nguồn nước dựa trên các quy định trong Hiệp định Mê Công 1995 và Công ước 1997 của Liên hợp quốc.

Từ khóa: Phát triển tuoói, Mê Công, dòng chảy, thuỷ điện, mùa khô, mùa mura.

Ban Biên tập nhận bài: 15/04/2019 Ngày phản biện xong: 22/06/2019 Ngày đăng bài: 25/07/2019

\section{1. Đặt vấn đề}

Sông Mê Công là một trong những sông lớn nhất thế giới, là nguồn tài nguyên nước đáng kể và quan trọng nhất khu vực Đông Nam Á với diện tích lưu vực rộng $795.000 \mathrm{~km}^{2}$ và tổng lượng dòng chảy năm khoảng 475 tỷ $\mathrm{m}^{3}$ (thứ 8 thế giới) [2]. Sông bắt nguồn từ cao nguyên Tây Tạng có độ cao khoảng 4500m, chảy qua vùng Tân Cương với chiều dài khoảng $800 \mathrm{~km}$ trước khi vào Vân Nam. Vùng trung và hạ lưu bắt nguồn từ vùng tam giác vàng giữa 3 nước Lào, Thái Lan và Myanma, với độ cao khoảng $500 \mathrm{~m}$, chiều dài sông từ đây ra biển khoảng hơn 2500km (Hình 1).

\footnotetext{
${ }^{1}$ Viện Khoa học tài nguyên nước, Bộ Tài nguyên và Môi trường

${ }^{2}$ Văn phòng Thuoòng trục Ủy ban sông Mê Công Việt Nam, Bộ Tài nguyên và Môi trường

Email:nganhduc@yahoo.com
}

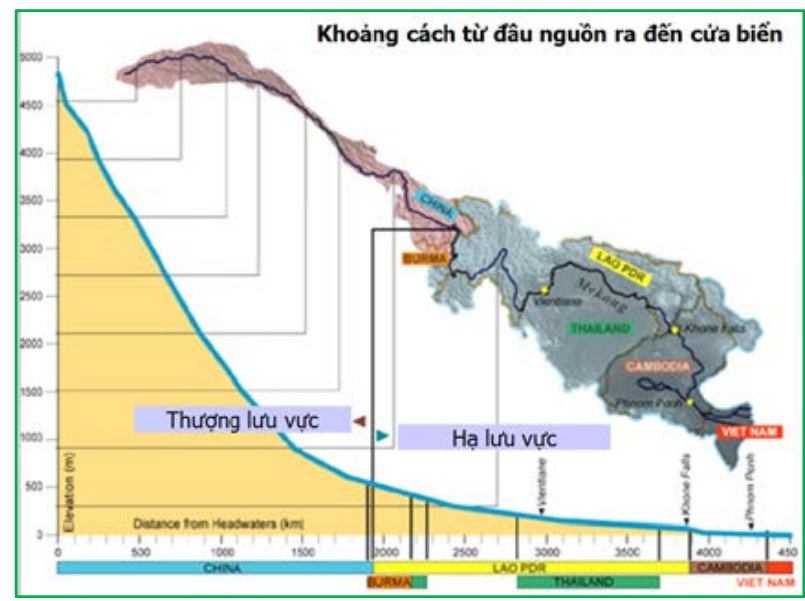

Hình 1. Tổng quan lưu vục sông Mê Công [2]

Sông Mê Công hiện nay và trong tương lai đóng vai trò quan trọng không chỉ trong sự phát triển kinh tế của mỗi quốc gia ven sông mà còn cả trong sự phát triển hợp tác kinh tế và chính trị 
trong khu vực. Nhu cầu khai thác và sử dụng tài nguyên nước và tài nguyên liên quan trong lưu vực sông Mê công tại các nước ven sông sẽ ngày càng lớn và chắc chắn sẽ tăng đáng kể trong tương lai, do đó việc chia sẻ công bằng, hợp lý, phát triển bền vững và bảo vệ nguồn tài nguyên nước và tài nguyên liên quan đã và đang trở thành một đòi hỏi lớn thiết thực. Trong khoảng một thập kỷ gần đây, thông tin về các hoạt động phát triển sử dụng tài nguyên nước sông Mê Công ở các quốc gia thượng nguồn như Trung Quốc, Thái Lan, Lào và Campuchia liên tục được cập nhật và thu hút mối quan ngại của Chính phủ và các cấp Bộ ngành địa phương của Việt Nam. Các phát triển này bao gồm phát triển thủy điện, chuyển nước trong và ngoài lưu vực, phát triển sử dụng nước tưới, phát triển công nghiệp và giao thông thủy, đã gây ra nhiều lo lắng về các tác động đến dòng chảy và các hệ quả về môi trường, kinh tế và xã hội của toàn lưu vực sông Mê Công và đặc biệt là vùng Đồng bằng sông Cửu Long (ĐBSCL) của Việt Nam. Chính vì vậy, việc thu thập thông tin, nghiên cứu, đánh giá định lượng được ảnh hưởng của các hoạt động phát triển này là rất cần thiết.

Trong bài báo này chúng tôi trình bày các kết quả nghiên cứu phân tích hiện trạng và đánh giá phân bố dòng chảy trong điều kiện phát triển các dự án tưới phục vụ sản xuất nông nghiệp của các quốc gia thượng lưu đến phân phối dòng chảy trên lưu vực sông Mê Công. Kết quả của nghiên cứu này là cơ sở đề xuất các nội dung và giải pháp cho công tác đàm phán của Việt Nam về chia sẻ nguồn nước trên lưu vực sông Mê Công theo Hiệp định Mê Công 1995 và Công ước 1997 của Liên hợp quốc.

\section{Phương pháp nghiên cứu và thu thập tài liệu}

\subsection{Giới thiệu khu vục nghiên cúu}

\section{1) Điều kiện khí tương thủy văn}

Khí hậu vùng sông Mê Công được phân thành 2 mùa rõ rệt với khoảng thời gian tương đối bằng nhau, mùa mưa bắt đầu từ khoảng giữa tháng 5 và kết thúc vào cuối tháng 9 đầu tháng 10 . Lượng mưa 6 tháng mùa mưa chiếm đến hơn $85 \%$ lượng mưa cả năm; lượng mưa 6 tháng mùa khô chỉ chiếm 15\% trong đó có những tháng không đo đạc được chút mưa nào. Vào cuối mùa mưa, ảnh hưởng của các trận bão và áp thấp nhiệt đới đến lưu vực đã làm cho các tháng 8 , tháng 9 thậm chí tháng 10 (vùng đồng bằng sông Cửu Long) là tháng có lượng mưa nhiều nhất. Thời gian mùa khô và mùa mưa không thay đổi từ thượng lưu xuống hạ lưu, nhưng có sự thay đổi về thời điểm lượng mưa trung bình tháng lớn nhất. Vùng thượng lưu, phía bắc lưu vực (tại Chiang Rai) lượng mưa tháng lớn xảy ra vào tháng 8 trong khi đó xuống tới hạ lưu, lượng mưa tháng lớn nhất lại xảy ra vào tháng 10 (tại Châu Đốc). Biến đổi của nhiệt độ trung bình ở các vùng đồng bằng và thung lũng sông của lưu vực là tương đối nhỏ, thể hiện tính chất nhiệt đới và cận nhiệt đới của khí hậu.

2) Tình hình khai thác và phát triển tài nguyên nước tại lư vực sông Mê Công

Nhu cầu khai thác tài nguyên nước phục vụ phát triển kinh tế-xã hội ở 5 nước thượng lưu sông Mê Công rất lớn. Trung Quốc đã khai thác tiềm năng thuỷ điện trên dòng chính Mê Công. Khai thác tiềm năng thuỷ điện cũng đang được thúc đẩy phát triển ở Lào và Campuchia $[3,5,9]$. Đặc biệt, các dự án nghiên cứu nhằm khai thác nguồn nước sông Mê Công phục vụ tưới cho nông nghiệp đã được phía Thái Lan tiến hành trong nhiều thập kỷ qua, chủ yếu tập trung vào các định hướng sau: (i) tăng cường sử dụng hiệu quả nguồn tài nguyên nước trên các sông nhánh của lưu vực sông Mê Công trong vùng Đông Bắc Thái Lan; (ii) tìm kiếm các phương án chuyển nước trong lưu vực từ phía Lào (qua dòng chính sông Mê Công) để bổ sung thêm nguồn nước cho các hồ chứa trong vùng Đông Bắc Thái Lan; và (iii) lấy nước trực tiếp từ dòng chính sông Mê Công để sử dụng cho vùng Đông Bắc Thái Lan. Camphuchia cũng phát triển vùng dự án thủy lợi Vai Co nằm ở đồng bằng trung tâm tại Đông Nam Campuchia. Các dự án chuyển nước và thủy lợi này sẽ có tác động đặc biệt tiêu cực đến các nước hạ lưu, nếu việc chuyển nước được thực hiện vào mùa khô [6]. Vì vậy, việc đánh giá ảnh hưởng của chúng lên phân phối dòng chảy sông Mê Công là hết sức cần thiết. 


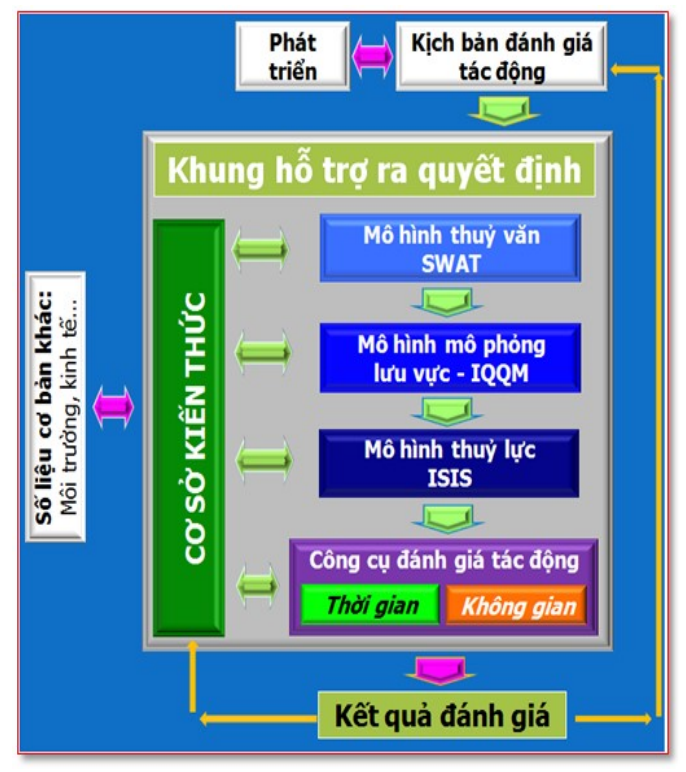

Hình 2. Khung hỗ trọ ra quyết định DSF

\subsection{Giới thiệu công cụ mô hình toán}

Nghiên cứu này sử dụng bộ công cụ mô hình toán của Uỷ hội sông Mê Công quốc tế (Decision Support Framework - DSF - Khung Hỗ trợ ra Quyết định) (Hình 2). Để phục vụ mục tiêu tính toán phân bố dòng chảy vào đồng bằng sông Cửu Long, nghiên cứu này chỉ sử dụng mô hình SWAT và mô hình IQQM. Trong đó mô hình SWAT được sử dụng để mô phỏng quá trình mưa - dòng chảy và mô hình IQQM dùng để tính toán mô phỏng cân bằng nước trên lưu vực và diễn toán dòng chảy trên sông $[7,8]$.

\section{1) Mô hình thủy văn SWAT}

SWAT là mô hình được phát triển bởi Bộ Nông nghiệp Mỹ (USDA) để mô phỏng diễn biến dòng chảy và chất lượng nước mặt, nước ngầm trên qui mô lưu vực dựa trên các đánh giá lượng mưa, khả năng bốc hơi tiềm năng và các đặc điểm về địa hình, loại đất và thảm phủ trong từng tiểu lưu vực [1]. Mô hình cho phép đánh giá các tác động đến môi trường của sử dụng đất, qui hoạch sử dụng đất và biến đổi khí hậu. Toàn bộ phần lưu vực sông Mê Công được chia thành 11 vùng như hình 3 . Tuy nhiên, do nghiên cứu này tập trung đánh giá dòng chảy đến đồng bằng

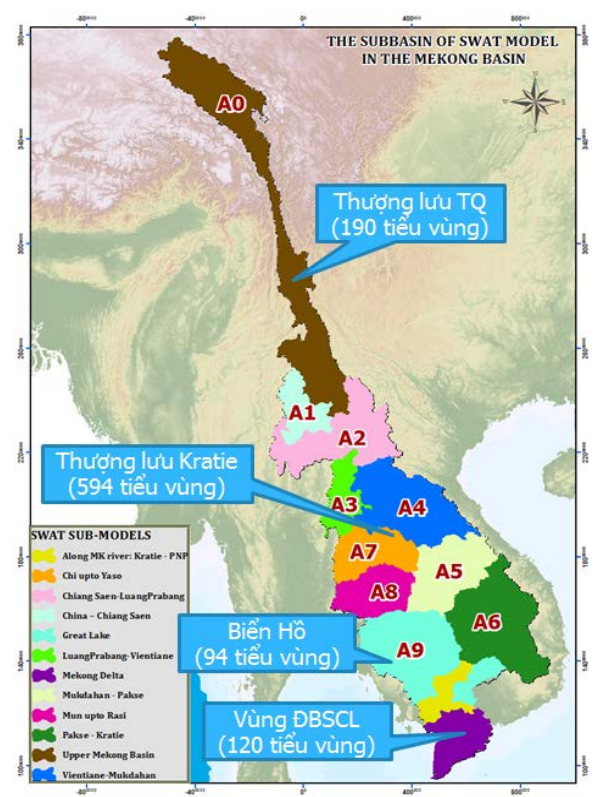

Hình 3. Phạm vi mô hình SWAT

sông Cửu Long nên dòng chảy vùng A10 thuộc Đồng bằng sông Cửu Long không được xem xét. Với mỗi vùng từ $\mathrm{A} 0$ đến $\mathrm{A} 9$, một mô hình SWAT sẽ được xây dựng. Mỗi vùng lại được chia nhỏ thành các tiểu lưu vực. Tổng cộng, có 10 mô hình SWAT và 870 tiểu lưu vực. Dòng chảy tại các cửa ra của lưu vực tính toán từ mô hình SWAT sẽ là đầu vào cho mô hình lưu vực IQQM.

\section{2) Mô hình mô phỏng luu vục IQQM}

IQQM được phát triển để mô phỏng lưu vực Murray- Darling ở Australia. Mô hình mô phỏng diễn toán dòng chảy trong lưu vực qua hệ thống sông, và các hệ thống thuỷ lợi điều tiết như đập và các công trình thuỷ lợi [4]. Mô hình IQQM còn sử dụng các số liệu trong Cơ sở Kiến thức để ước tính nhu cầu nước tưới trên toàn lưu vực sông Mê Công. Hình 4 trình bày sơ đồ mô phỏng dòng chảy cho lưu vực sông Mê Công sử dụng mô hình IQQM được Ủy hội sông Mê Công quốc tế xây dựng với các dòng gia nhập từ đầu ra của mô hình SWAT, 37 đập dòng nhánh và 420 điểm lấy nước (dân sinh, công nghiệp), và 366 khu đất canh tác nông nghiệp. 


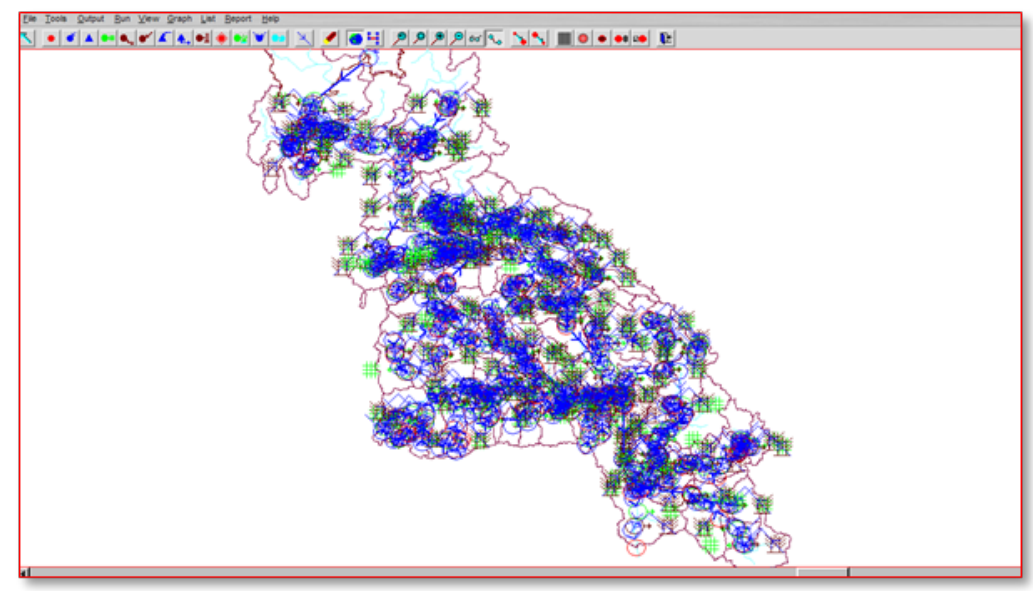

Hình 4. So đồ tính toán mô hình IQMM

\subsection{Số liệu đầu vào}

Tài liệu khí tượng, thuỷ văn: Chuỗi số liệu mưa, bốc hơi, lưu lượng và mực nước ngày trong giai đoạn 1980 - 2008 của các trạm trên lưu vực được trích trong cơ sở dữ liệu của Khung hỗ trợ ra quyết định DSF. Bộ số liệu này đã được chỉnh biên và được đánh giá là có chất lượng đảm bảo yêu cầu tính toán, mô phỏng.

Tài liệu địa hình: Bản đồ cao độ DEM cho toàn lưu vực với độ phân giải $250 \mathrm{~m}$ được sử dụng phục vụ phân chia lưu vực thành các tiểu lưu vực và mô phỏng quá trình thuỷ văn bằng mô hình SWAT (Hình 5a).

Tài liệu về thảm phủ: Bản đồ độ che phủ rừng của hạ lưu vực sông Mê Công được xây dựng từ không ảnh năm 1997 và 2003. Vùng thượng nguồn (Phần diện tích Trung Quốc và Myanma) và vùng rừng che phủ ít hoặc không che phủ (các khu vực ngập lũ và đồng bằng sông Cửu Long) thì sử dụng bản đồ sử dụng đất toàn cầu (Hình 5b).

Tài liệu về thổ nhưỡng: Bản đồ đất của lưu vực sông Mê Công (trừ phần bị ngập lũ sâu ở hạ lưu) được lấy từ bản đồ đất của Tổ chức lương thực thế giới FAO. Bản đồ đất phần hạ lưu ngập lũ được Uỷ hội sông Mê Công (MRCS) hoàn thiện vào tháng 6 năm 2002 (Hình 5c).

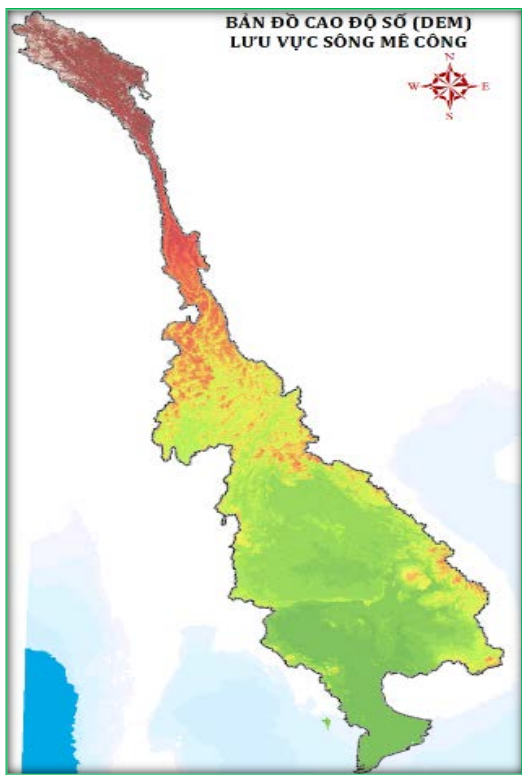

(a)

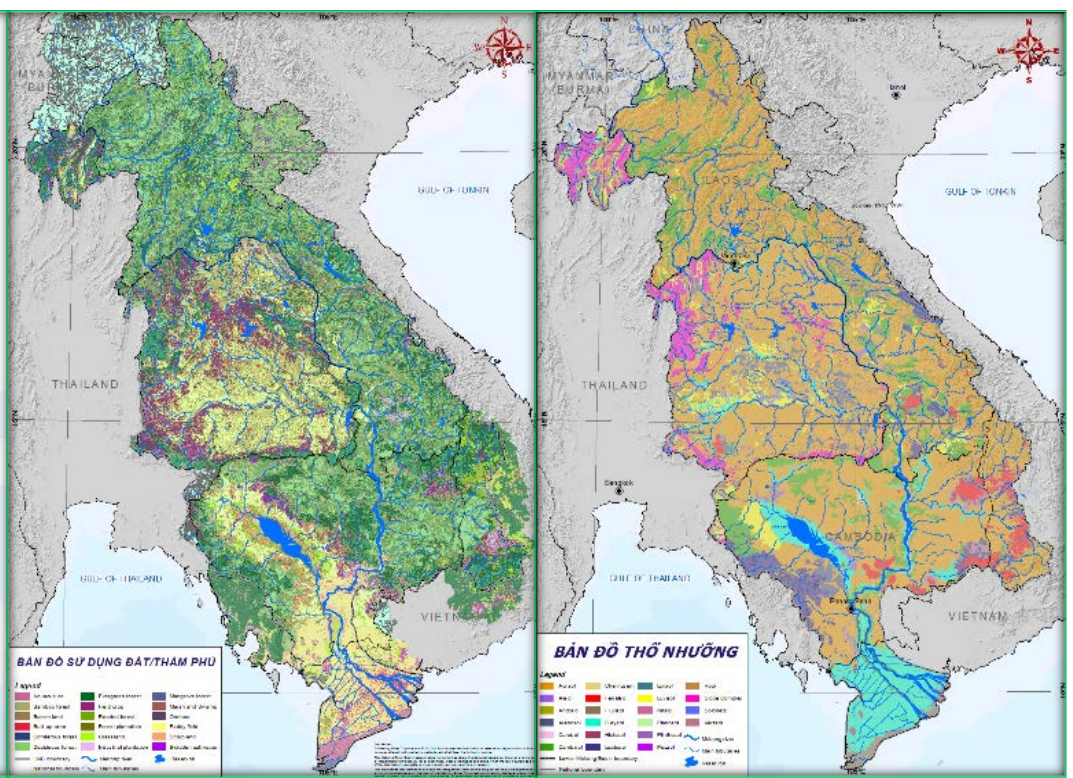

(b) (c)

Hình 5. Bản đồ DEM, thảm phủ và thổ nhương lưu vực sông Mê Công: (a) DEM; (b) Bản đồ thảm phủ; (c) Bản đồ thổ nhương 


\subsection{Phân vùng lưu vục tính toán}

Tính toán cân bằng nước được thực hiện cho 70 tiểu lưu vực, sau đó gộp thành 16 vùng trong đó Trung Quốc: 1 vùng $(1 \mathrm{CN})$, Myanmar 1 vùng (1MA), Lào: 5 vùng (1L, 3L, 4L, 6L, 7L), Thái Lan: 3 vùng (2T, $3 \mathrm{~T}, 5 \mathrm{~T})$, Campuchia: 4 vùng $(7 \mathrm{C}, 8 \mathrm{C}, 9 \mathrm{C}, 10 \mathrm{C})$ và Việt Nam: 2 vùng $(7 \mathrm{~V}$, 10V) (Hình 6) [3]. Tuy nhiên, trong nghiên cứu này chúng tôi tập trung tính toán dòng chảy đến vùng đồng bằng sông Cửu Long nên chưa xem xét phân tích chi tiết trong vùng $10 \mathrm{~V}$.

\subsection{Các kịch bản tính toán}

Một kịch bản nền và ba kịch bản tính toán về phân bố dòng chảy trong nghiên cứu này được thể hiện như ở bảng 1 . Trong đó, ở các kịch bản 2020 và $2060 \mathrm{~A}$, các hồ chứa được xây dựng trong tương lai tham gia vào quá trình điều tiết dòng chảy. Ở kịch bản 2060B các hồ chứa được xây dựng mới trong tương lai không tham gia vào quá trình điều tiết dòng chảy nhằm đánh giá tác động riêng rẽ của hoạt động phát triển tưới đến phân phối dòng chảy.

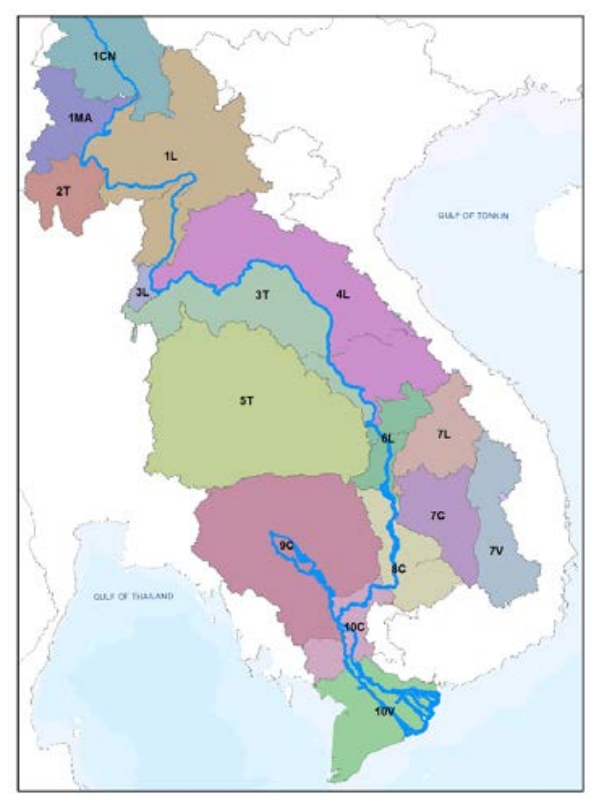

Hình 6. So đồ phân vùng tính toán tại lưu vực sông Mê Công

Bảng 1. Các kịch bản tính toán mô phỏng phân bố dòng chảy

\begin{tabular}{|c|c|c|c|}
\hline $\begin{array}{l}\text { Tên kịch } \\
\text { bản }\end{array}$ & Tên kịch bản & $\begin{array}{l}\text { ĐK } \\
\text { thuỷ } \\
\text { văn }\end{array}$ & Hồ chứa và đập dâng \\
\hline $\begin{array}{l}\text { Kịch } \\
\text { bản nền } \\
\text { BL }\end{array}$ & $\begin{array}{l}\text { Điều kiện } \\
\text { phát triển hiện } \\
\text { tại } 2007\end{array}$ & & $\begin{array}{l}\text { Các đặc trưng như: Sử dụng đất, Kênh mương, Giao thông, } \\
\text { Đập, Hồ chứa, Vận hành hồ chứa như năm } 2007 \text {. Hệ́ thống đập } \\
\text { vầ hồ chứa: Lào có } 5 \text { đập; Việt Nam } 1 \text { đập; Đông bắc Thái Lan } \\
\text { có } 12 \text { đập. }\end{array}$ \\
\hline $\begin{array}{l}\text { Kịch } \\
\text { bản } \\
2020\end{array}$ & $\begin{array}{l}\text { Điều kiện } \\
\text { phát triến đến } \\
\text { 2020, các hồ } \\
\text { chứa tham gia } \\
\text { điều tiết } \\
\text { chống hạn }\end{array}$ & & $\begin{array}{l}\text { - Thêm } 02 \text { đập trên sông chính thuộc hạ lưu vực trên sông MK } \\
\text { (Xayaburi va Donsahong). Chế độ vận hành được xem xét } \\
\text { trong điều kiện tối ưu và điều kiện tăng cường tích nước phục } \\
\text { vụ cho phát điện. } \\
\text { - Hệ thống đập trên các sông nhánh, Hệ thống kiểm soát lũ, } \\
\text { Diện tich tưới và các dự án chuyển nước trong lưu vực theo } \\
\text { quy hoạch như BDP đến } 2020 \text { [3]. }\end{array}$ \\
\hline $\begin{array}{l}\text { Kịch } \\
\text { bản } \\
2060 \mathrm{~A}\end{array}$ & $\begin{array}{l}\text { Điều kiện } \\
\text { phát triển đến } \\
\text { 2060, các hồ } \\
\text { chứa tham gia } \\
\text { điều tiết } \\
\text { chống hạn }\end{array}$ & $\begin{array}{c}\text { Basline } \\
1985- \\
2008\end{array}$ & $\begin{array}{l}\text { - Thêm } 11 \text { đập trên sông chính thuộc hạ lưu vực trên sông } \\
\text { MK. Chế độ vận hành cũng được xem xét trong điều kiện tồi } \\
\text { ưu và điều kiện tăng cường tích nước phục vụ cho phát điện. } \\
\text { - Hệ thống đập trên các sông nhánh, Hệ thống kiểm soát lũ, } \\
\text { Diện tích tưới và các dự án chuyển nước trong lưu vực theo } \\
\text { quy hoạch như Chương trình phát triển lưu vực (BDP) đến }\end{array}$ \\
\hline $\begin{array}{l}\text { Kịch } \\
\text { bản } \\
2060 \mathrm{~B}\end{array}$ & $\begin{array}{l}\text { Điều kiện } \\
\text { phát triển đến } \\
\text { 2060, các hồ } \\
\text { chứa không } \\
\text { tham gia điều } \\
\text { tiết chống hạn }\end{array}$ & & $\begin{array}{l}2060 \text { [3]. } \\
\text { Các án thủy lợi, tưới và chuyển nước trong luu vực bao gồm } \\
\text { các dự án Nọng Khai Chi Mun, Huồi Luông - Chi Mun, Loei- } \\
\text { ChiMun, Xê bang Phai - Chi Mun, Vai-Co } \\
\text { Các dự án chuyển nước ra ngoài luu vực bao gồm các dự án } \\
\text { Kok-Mea Ngat, Kok-Ing-Yorn, MC-Skirit, Kok-Ing-Nan, } \\
\text { Loei-Sane. }\end{array}$ \\
\hline
\end{tabular}




\section{Kết quả tính toán}

\subsection{Kết quả hiệu chỉnh, kiểm định mô hình}

\section{SWAT và IQQM}

Chuỗi số liệu từ năm 1985 đến 2000 được dùng hiệu chỉnh mô hình SWAT và IQQM, và từ 2001 đến 2008 được dùng để kiểm định các mô hình này. Hình 7 so sánh lưu lượng thực đo và tính toán sau khi được hiệu chỉnh tại Chiềng-Sen và Kra-chê giai đoạn 1985-2008. Quá trình dòng chảy mô phỏng tại 2 trạm trên dòng chính sông Mê Công đều phù hợp rất tốt với quá trình dòng chảy thực đo. Kết quả hiệu chỉnh, kiểm định tại các trạm trên dòng chính đều đạt độ chính xác rất cao với chỉ số Nash lớn hơn hoặc bằng 0,9 , sai số tổng lượng hầu như không đáng kể.

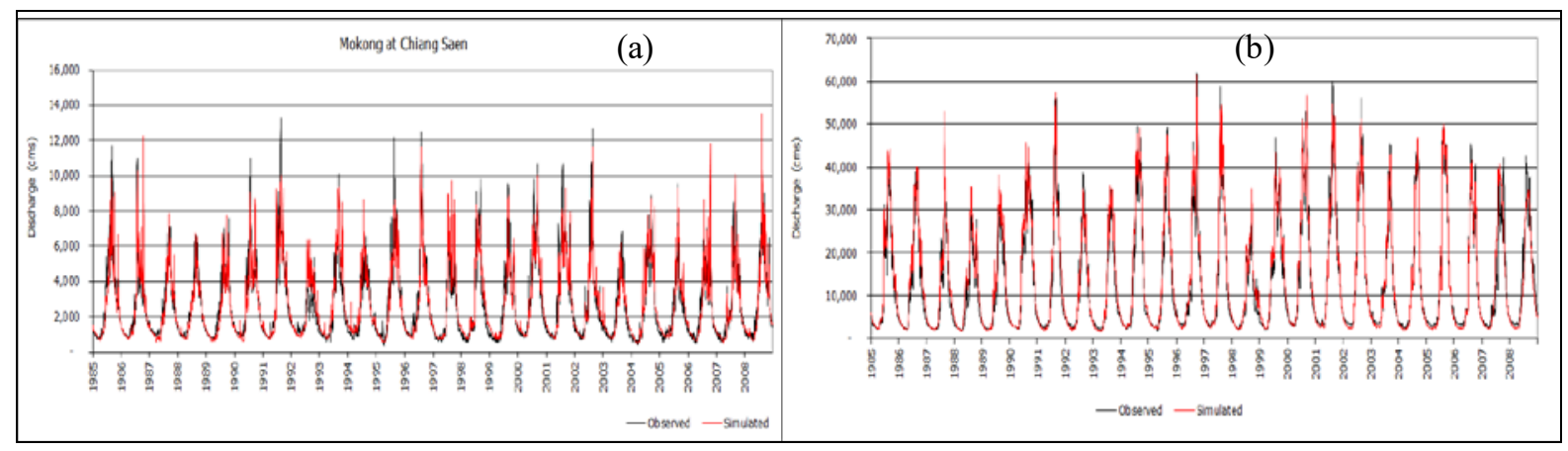

Hình 7. Dòng chảy TB ngày tại Chiang Saen (a) và Kratie (b) giũ̃a tính toán và thực đo

\subsection{Kết quả tính toán phân phối dòng chảy}

3.2.1. Hiện trạng phân bố dòng chảy trên lưu vự sông Mê Công

Hình 8 thể hiện phân bố dòng chảy theo các vùng và theo quốc gia trên lưu vực sông Mê Công. Tổng lượng dòng chảy trung bình năm (đến đồng bằng sông Cửu Long) vào khoảng 473 tỉ $\mathrm{m} 3$ trong đó mùa khô chiếm lượng dòng chảy rất nhỏ (chỉ khoảng 14\%), trong khi đó mùa mưa chiếm tới $86 \%$. Về đóng góp dòng chảy của các quốc gia, sông Lan Thương Trung Quốc đóng góp 15\% trong đó mùa khô đóng góp nhiều hơn (22\%) mùa mưa (14\%). Như vậy, phần thượng lưu Trung Quốc đóng vai trò rất quan trọng về lượng dòng chảy, đặc biệt là vào mùa khô. Đóng góp lớn nhất vào tổng dòng chảy trên sông Mê Công là Lào, chiếm 46\% tổng lượng dòng chảy năm. Mặc dù đóng góp vẫn rất lớn nhưng đóng góp cho dòng chảy mùa khô của Lào nhỏ hơn mùa mưa (41\% dòng chảy mùa khô và $47 \%$ dòng chảy mùa mưa). Đóng góp vào dòng chảy của Thái Lan và Campuchia vào tổng dòng chảy năm tương đối bằng nhau (khoảng 14\%), tuy nhiên đóng góp của Campuchia vào dòng chảy mùa khô (12\%) lớn hơn của Thái Lan (8\%). Đóng của phần lưu vực Sesan-Srepok của Việt Nam vào khoảng $7 \%$. Đóng góp của phần lãnh thổ Myanmar nhỏ nhất (khoảng gần 4\%). Có thể nhận thấy, tuy chiếm diện tích lưu vực tương đối lớn nhưng do lượng mưa tương đối nhỏ nên dòng chảy sinh ra trên địa phận Thái Lan và Campuchia tương đối thấp. Đây cũng là lý do Thái Lan và Campuchia tích cực nghiên cứu các dự án lấy nước từ sông Mê Công phục vụ tưới để phát triển nông nghiệp. 


\section{BÀI BÁO KHOA HỌC}

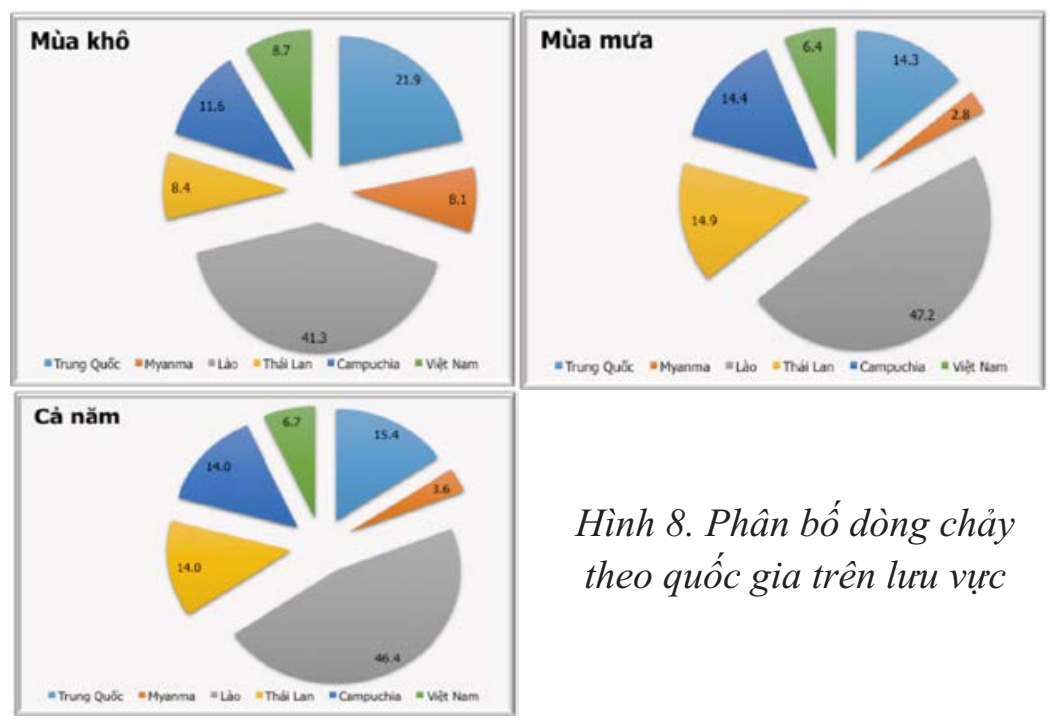

3.2.2. Kịch bản phát triển đến năm 2020 và 2060 có tính đến hoạt động điều tiết của các hồ chía

Hình 9 trình bày mức độ thay đổi dòng chảy trong điều kiện phát triển đến năm 2020 và 2060 và các hồ chứa tham gia điều tiết dòng chảy mùa. Phân bố dòng chảy thay đổi như sau: Đóng góp dòng chảy cả năm của phần thượng lưu lưu vực sông trên địa phận Trung Quốc gần như không đổi. Tuy nhiên, có sự thay đổi tương đối lớn về dòng chảy mùa kiệt và mùa lũ do điều tiết của các hệ thống hồ chứa mới được xây dựng trong giai đoạn 2007-2020. Đóng góp của dòng chảy mùa kiệt tăng $26 \%$ và dòng chảy mùa lũ giảm $6,4 \%$ trong điều kiện vận hành tối ưu của các hồ chứa. Dòng chảy mùa mưa, mùa khô và cả năm trên phần lãnh thổ Myanmar không có sự thay đổi đáng kể giữa kịch bản nền và 2 kịch bản tương lai. Đối với Lào, thay đổi tỉ lệ đóng góp dòng chảy năm của vùng $1 \mathrm{~L}$ tương đối lớn (giảm $9,3 \%$ theo kịch bản năm 2020 và $9,7 \%$ theo kịch bản năm 2060). Ở vùng này, do điều tiết của các hồ chứa mới được xây dựng trên dòng chính, dòng chảy mùa mưa giảm một lượng đáng kể (giảm $12,1 \%$ và $14,4 \%$ tương ứng với các kịch bản 2020 và 2060). Mặc dù dòng chảy mùa khô tăng (9\% và $21 \%)$ nhưng do nước phục vụ các nhu cầu dùng nước (và không hồi qui lại hoàn toàn) tăng lên nên dòng chảy năm giảm. Các vùng $3 \mathrm{~L}$ và $4 \mathrm{~L}$, dòng chảy năm thay đổi không đáng kể. Tuy nhiên, do điều tiết của các hồ chứa dòng chảy vùng $4 \mathrm{~L}$ mùa khô tăng khá lớn, lần lượt là $30,3 \%$ và $32 \%$, mùa mưa giảm $3,2 \%$ và $4,5 \%$ tương ứng với năm 2020 và 2060 . Không có sự thay đổi đáng kể giữa phân phối dòng chảy năm 2020 và 2060 trên phần lãnh thổ của Trung Quốc, Myanmar và Lào, chứng tỏ không có thêm công trình lớn nào được xây dựng trong giai đoạn 2020-2060 ở các khu vực này.

Với Thái Lan, dòng chảy mùa mưa, mùa khô và cả năm vùng $2 \mathrm{~T}$ đều tăng một lượng nhỏ do hoạt động lấy nước từ sông Mê Công vào phục vụ tưới. Vùng $3 \mathrm{~T}$ không có sự thay đổi dòng chảy đáng so với kịch bản nền. Đặc biệt, vùng $5 \mathrm{~T}$ theo kịch bản 2020 thì dòng chảy năm và các mùa đều giảm do sự gia tăng nhu cầu nước tưới. Tuy nhiên, đến năm 2060, dòng chảy các mùa và tổng dòng chảy năm ở vùng $5 \mathrm{~T}$ đều tăng mạnh. Dòng chảy mùa kiệt tăng mạnh nhất $(55,4 \%)$, dòng chảy mùa mưa tăng $6,3 \%$ và dòng chảy cả năm tăng 9,8\%. Điều này là do việc xây dựng các công trình chuyển nước từ sông Mê Công vào vùng này phục vụ tưới cho nông nghiệp trong giai đoạn 2020 - 2060 trên phần lưu vực này. Một phần lượng nước được chuyển sẽ trả lại cho sông Mê Công dưới dạng dòng chảy hồi qui nên có sự gia tăng đóng góp dòng chảy đột ngột của vùng $5 \mathrm{~T}$. 

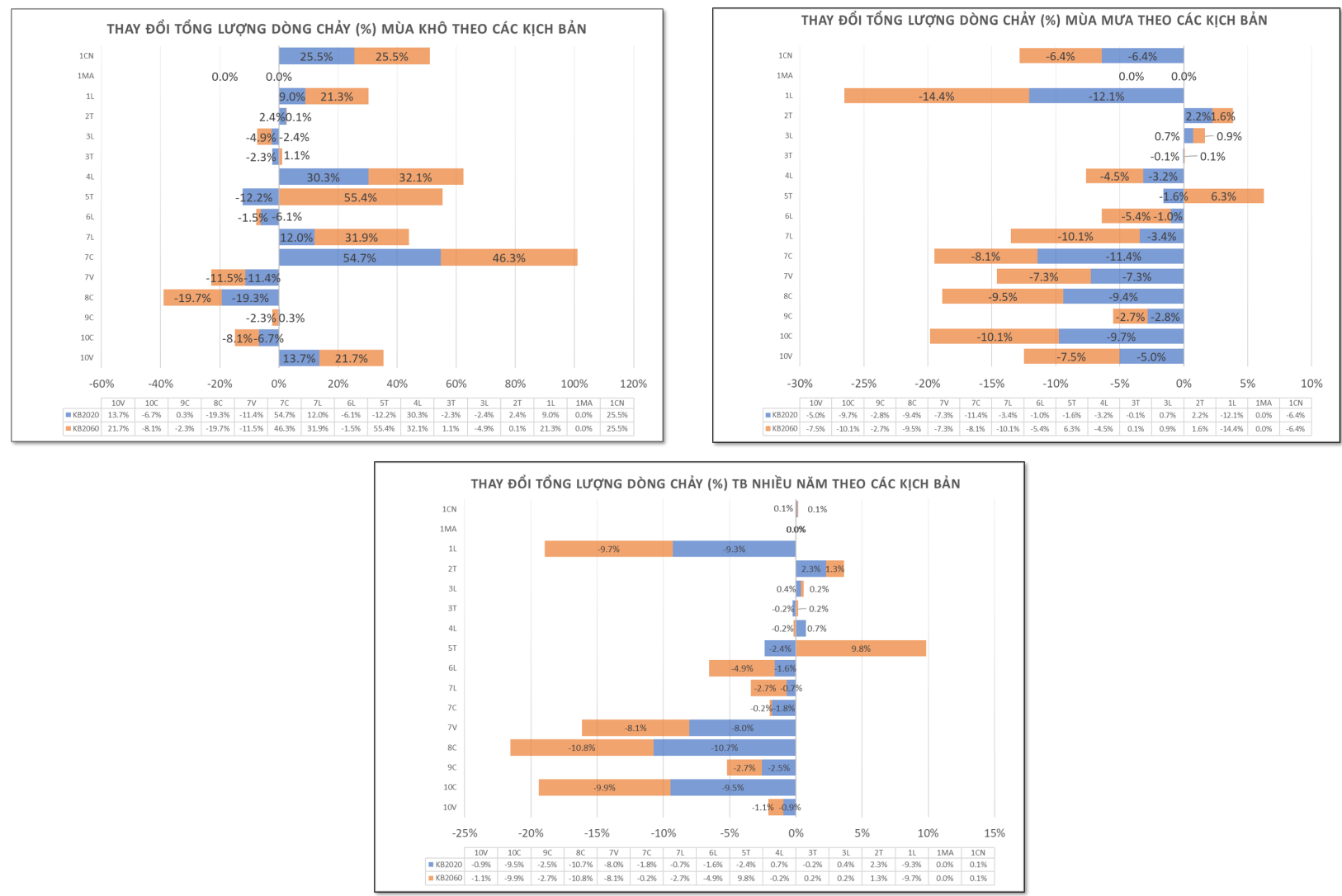

Hình 9. Mức thay đổi của dòng chảy mùa khô, mùa mưa và cả năm của các kịch bản 2020 và 2060 so với kịch bản nền (2007)

Đóng góp dòng chảy năm và các mùa từ nhánh của Campuchia đều giảm do việc phát triển tưới (dòng chảy năm giảm lên đến $10,8 \%$ tại vùng $8 \mathrm{C}$ ). Tương tự, đóng góp dòng chảy từ sông Sesan và Srepok (vùng $7 \mathrm{~V}$ ) của Việt Nam cũng giảm. Theo kịch bản 2060, dòng chảy giảm $11,5 \%$ về mùa kiệt và $7,3 \%$ về mùa lũ, dẫn đến tổng dòng chảy năm giảm $8,1 \%$. Điều này là do nhu cầu sử dụng nước ở các vùng này tăng mạnh trong tương lai đã làm giảm đóng góp dòng chảy ở cả mùa lũ và mùa kiệt. Không có sự khác biệt lớn giữa đóng góp dòng chảy theo 2 kịch bản 2020 và 2060 của phần lưu vực trên địa phận Campuchia và Việt Nam.

3.2.3. Kịch bản phát triển đến năm 2060 không tính đến hoạt động điều tiết của các hồ chúa

Hình 10 trình bày kết quả đóng góp dòng chảy của các tiểu vùng khi xem xét ảnh hưởng của hoạt phát triển tưới và chuyển nước theo kịch bản 2060 nhưng không xem xét điều tiết của các hồ chứa dự kiến được xây dựng trên dòng chính sông Mê Công. Kết quả tính toán cho thấy hoạt động phát triển tưới và chuyển nước đã làm thay đổi tương đối lớn đóng góp dòng chảy của các tiểu vùng. Vùng $5 T$ của Thái Lan có đóng góp dòng chảy tăng đặc biệt trong mùa khô do nước lấy từ dòng chính sông Mê Công hồi qui lại. Dòng chảy mùa khô tăng $32,9 \%$ và dòng chảy cả năm tăng gần $2 \%$ ở vùng này. Phần lưu vực trên lãnh thổ Trung Quốc và Myanma dòng chảy thay đổi không đáng kể do hoạt động phát triển tưới và chuyển nước không ảnh hưởng nhiều đến dòng chảy ở đây. Các vùng chịu ảnh hưởng lớn nhất do nước bị lấy mất bao gồm $1 \mathrm{~L}, 4 \mathrm{~L}, 6 \mathrm{~L}, 7 \mathrm{~L}$ của Lào và $9 \mathrm{C}$ của Campuchia. Một điểm cần lưu ý khác là, trái ngược với kịch bản 2060A khi việc điều tiết các hồ chứa đã làm dòng chảy mùa khô tăng và dòng chảy mùa mưa giảm, dòng chảy mùa khô và mùa mưa của kịch bản $2060 \mathrm{~B}$ đều giảm (trừ vùng $5 \mathrm{~T}$ ) do nhu cầu dùng nước trên toàn lưu vực tăng và không được điều tiết bởi các hồ chứa. 


\section{BÀI BÁO KHOA HỌC}
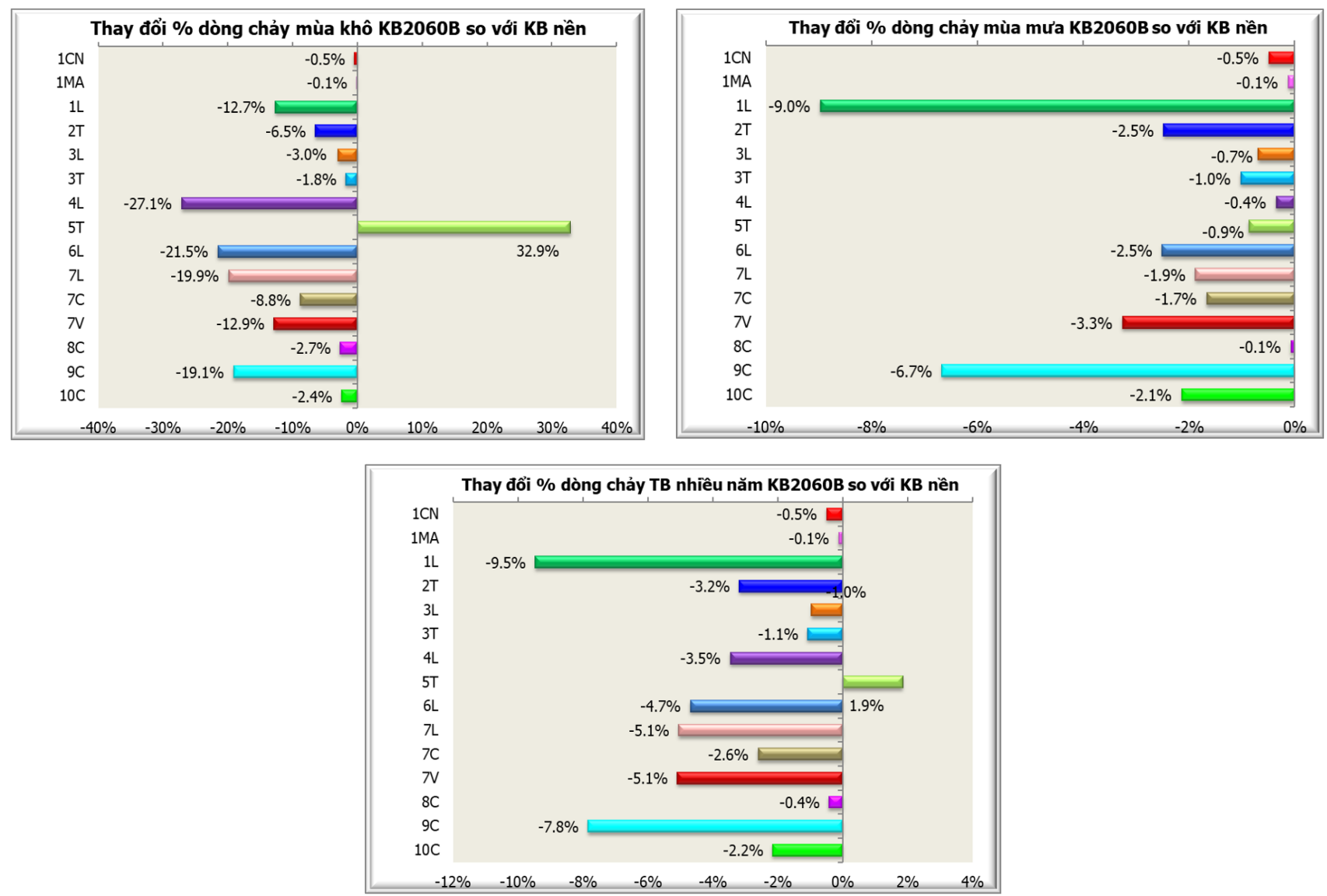

Hình 10. So sánh phân phối dòng chảy mùa khô, mùa mưa và cả năm trong điều kiện theo kịch bản phát triển 2060 không có hoạt động điều tiết của hồ chứa

\section{Kết luận}

Lưu vực sông Mê Công là một trong 8 lưu vực sông lớn nhất thế giới, đóng vai trò quan trọng về kinh tế, chính trị của mỗi quốc gia trên lưu vực sông nói riêng và trong khu vực nói chung. Do đó, sự thay đổi về dòng chảy trên sông Mê Công dưới tác động của các hoạt động khai thác tài nguyên nước có ảnh hưởng lớn tới sự hợp tác và phát triển trong khu vực. Trong bài báo này chúng tôi trình bày kết quả đánh giá phân phối dòng chảy trên lưu vực sông Mê Công và xem xét ảnh hưởng của các phát triển tưới và chuyển nước đến phân phối dòng chảy trên lưu vực. Bộ mô hình SWAT và IQQM đã được sử dụng phục vụ mục đích này.

Các kết quả tính toán cho thấy, tổng lượng dòng chảy năm trên lưu vực vào đồng bằng sông Cửu Long vào khoảng 473 tỉ $\mathrm{m} 3$ trong đó $86 \%$ dòng chảy tập trung vào 6 tháng mùa mưa, gây tình trạng lũ lụt vào mùa mưa và hạn hán vào mùa khô. Trong số các nước trên lưu vực, Lào đóng góp dòng chảy vào đồng bằng sông Cửu Long lớn nhất (46\%). Phần lưu vực trên địa phận Thái Lan và Campuchia tuy chiếm diện tích tương đối lớn nhưng do lượng mưa ở khu vực này tương đối nhỏ nên đóng góp chảy nhỏ (mỗi nước chiếm 14\% tổng dòng chảy năm).

So với kịch bản hiện trạng, kịch bản 2020 và 2060 trong điều kiện các hồ chứa tham gia điều tiết dòng chảy cho thấy, phần lưu vực thuộc địa phận Trung Quốc không có sự thay đổi lớn về tổng lượng dòng chảy năm nhưng dòng chảy mùa khô tăng lên và dòng chảy mùa mưa giảm đi. Vùng lãnh thổ Lào, việc xây dựng các thủy điện theo kế hoạch cũng sẽ làm dòng chảy tăng về mùa khô và giảm về mùa mưa. Ở một số lưu vực, do bốc hơi và dòng chảy sau khi sử dụng cho tưới không hồi qui hết nên tổng dòng chảy năm giảm. Với Thái Lan, do các hoạt động lấy nước tưới phục vụ phát triển nông nghiệp, đóng góp dòng chảy các mùa và dòng chảy năm ở vùng $2 \mathrm{~T}$ và $5 \mathrm{~T}$ đều tăng. Đặc biệt, dòng chảy 
mùa kiệt vùng $5 \mathrm{~T}$ tăng tới $55,4 \%$ và dòng chảy mùa mưa tăng $6,3 \%$, dẫn đến dòng chảy cả năm tăng 9,8\% ở kịch bản 206A. Đóng góp dòng chảy năm và các mùa của Campuchia và phần lưu vực Sesan-Srepok của Việt Nam (7V) đều giảm do nhu cầu sử dụng nước ở các vùng này tăng mạnh trong tương lai. Tuy nhiên khi xem xét trường hợp có phát triển tưới và chuyển nước nhưng không xem xét tác động điều tiết của các hồ chứa dự kiến được xây dựng trên dòng chính sông Mê Công thì dòng chảy mùa kiệt trên toàn lưu vực (ngoại trừ vùng $5 \mathrm{~T}$ ) giảm đáng kể nhất là ở các vùng bị lấy nước phục vụ phát triển tưới và chuyển nước.

Nghiên cứu này cung cấp các thông tin quan trọng về phân bố dòng chảy trên lưu vực sông Mê Công trong điều kiện hiện trạng và tương lai theo các kịch bản sử dụng nước khác nhau, phục vụ công tác đàm phán, hợp tác giữa các quốc gia trên lưu vực. Đặc biệt, là một nước nằm ở hạ lưu sông Mê Công, sự biến động dòng chảy có ảnh hưởng trực tiếp đến Việt Nam. Vì vậy, kết quả của nghiên cứu này sẽ cung cấp thông tin cho các nhà quản lý, ngoại giao trong việc đàm phán về chia sẻ nguồn nước sông Mê Công theo hiệp định 1995 và công ước 1997 của Liên Hợp Quốc.

Lời cảm ơn: Kết quả nghiên cứu được trình bày trong bài báo này là một phần nội dung của đề tài cấp Bộ "Nghiên cứu phân bố dòng chảy tại lưu vục sông Mê Công trong điều kiện phát triển sử dụng nuoóc tưới của các quốc gia lưu vực sông Mê Công phục vu cho công tác đàm phán của Việt Nam và chia sẻ nguồn nước trong thực hiện Hiệp định Mê Công 1995 và Công uớc 1997 của Liên hợp quốc” mã số TNMT.2017.02.16. Các tác giả xin chân thành cảm ơn Bộ tài nguyên môi truờng đã tài trợ đề tài này. Chúng tôi cũng xin cảm ơn Uỷ ban sông Mê Công Việt Nam đã cung cấp số liệu và bộ công cu mô hình toán giúp chúng tôi thực hiện nghiên cứu này.

\section{Tài liệu tham khảo}

1. Arnold, J.G., Moriasi, D.N., Gassman, P.W., Abbaspour, K.C., White, M.J., Srinivasan, R., Santhi, C., Harmel, R.D., van Griensven, A., Van Liew, M.W., Kannan, N., Jha, M.K. (2012), SWAT: Model use, calibration, and validation. Transactions of the ASABE, 55(4), 1491-1508.

2. Ban Thư ký Uỷ hội sông Mê Công quốc tế (2004), Báo cáo "Tổng quan điều kiện thuỷ văn Luu vực sông Mê Công".

3. Chương trình phát triển lưu vực (BDP) giai đoạn 2, MRCs (2009), Báo cáo "BDP2-Normal track Scenario".

4. Simons, M., Podger, G., Cooke, R. (1996), IQQM-A hydrologic modelling tool for water resource and salinity management. Environmental Software, 11(1-3), 185-192.

5. Sở điện lực Lào (2009), Báo cáo "Optimization study of Mekong Mainstream Hydropower", Viên Chăn.

6. Sở điện lực Thái Lan (2008), Báo cáo tóm tắt "The Cascade Run-of-River Hydropower Potential Development Projects on Mekong Mainstream”.

7. Uỷ ban sông Mê Công Việt Nam (2000), Báo cáo chuyên đề "Thu thập tài liệu, phân tích, đánh giá và viết báo cáo tổng hợp về các điều kiện tự nhiên, kinh tế, xã hội, các kế hoạch và dự kiến phát triển của 5 nước thượng nguồn sông Mê Công, gồm Miến Điện, Tỉnh Vân Nam (Trung Quốc), Lào, Thái Lan và Cămpuchia", Hà nội.

8. Uỷ ban sông Mê Công Việt Nam (2009), Báo cáo "Nghiên cứu tác động của Dự án chuyển nước sông Mê Công Loei - Ubol Rathana của Thái Lan tới vùng Đồng bằng sông Cưu Long, Việt Nam", Hà Nội

9. Ủy hội sông Mê Công quốc tế (2017), Báo cáo "Phát triển và quản lý bền vũng sông Mê Công, bao gồm cả tác động các công trình thủy điện”, Viên Chăn. 


\section{ANALYSIS OF FLOW DISTRIBUTION IN THE MEKONG RIVER BASIN AND ITS VARIATIONS UNDER THE IMPACT OF PLANNED IRRIGATION DEVELOPMENT PROJECTS \\ Nguyen Anh Duc', Tran Anh Phuong', Nguyen Dinh Dat ${ }^{2}$, Nguyen Huy Phuong², Pham Tuong ${ }^{2}$, Pham Nhat Anh ${ }^{1}$ \\ ${ }^{1}$ Water Resources Institute, Ministry of Natural Resources and Environment \\ ${ }^{2}$ Vietnam National Mekong Committee, Ministry of Natural Resources and Environment}

Abstract: This study aims at analyzing flow distribution in the Mekong River basin and assessing the impact of irrigation development projects, one of the "hot" water use issues in the basin besides hydropower development, on this distribution. Results show that the rainy season accounts for up to 86\% annual flow, which has caused floods in this season and droughts in the dry season. Among countries in the basin, Laos contributes the largest part flowing into the Vietnam Mekong Delta (46\%), followed by China (15\%). If water use projects are implemented as planned until 2060, the total flow of the wet season and annual flow across the basin will generally decrease. When the reservoirs positively participate in regulating the flow, the difference between the rainy and dry seasons in the catchment area of China, Laos and part of Cambodia (7C) will decrease. For Thailand, due to the intake of water from the Mekong River for agricultural irrigation, the seasonal and annual flow in the 5 T region will increase. The flow from Vietnam's Sesan-Srepok Basin (7V) decreased by $8.1 \%$ due to increased water demand. If the reservoirs do not participate in the flow regulation, the seasonal flow, especially in the dry season across the basin (except for the 5T area) significantly reduces. The results of this study will provide the necessary scientific basis for the negotiation and cooperation between Vietnam and other countries in the basin, who share the Mekong water according to the provisions of the 1995 Mekong Agreement and the United Nations Convention 1997.

Keywords: Mekong, flow distribution, irrigation development, seasonal flow, annual flow. 